\title{
一樂照雄の社会経済思想と日本の有機農産物 「産消提携」運動*
}

\section{I 本稿 の目的}

\section{根 本 志保子}

本稿では，一樂照雄（1906-1994）の協同組合思想と，一樂が 1970 年代日本の「有機農産物 の生産者と消費者の産消提携運動（以下，産消提携）」の指針として提唱した「生産者と消費者 の提携の方法 (以下, 提携 10 か条)」の学説史的意義を検討する.

「産消提携」とは，1970 年代初頭に「安全な食べ物の生産と消費」を目的として始まった「生 産者と消費者間の相互扶助的な食料流通システム」である. 各地の無農薬・無化学肥料栽培を試 みる生産者と安全な食べ物を求める消費者の自然発生的な結びつきに始まり, 生産物 / 出荷物を 全量引き取る, 出荷される農産物は季節や天候状沉に依存し消費者はその内容を選べない, 運 送 / 配分 / 会計などは流通事業者などの第三者を入れずに生産者と消費者会員自身により行われ る，などの特徵がある。農村の生産者と都市の消費者を直接結ぶ「提携」は，日本の初期の有機 農業と家族経営による少量多品種栽培を支え，継続させる役割を果たしてきた，同時に，消費者 による生活の見直しや生産者との情報共有, 消費者自身による農業体験/学習なども実践され, 消費者が当事者として農産物生産と流通に関わるという環境消費運動の側面をもつ，その活動と 組織は今日まで継続し，世界各地で拡大する地域コミュニティ農業（Community Supported Agriculture: CSA）のモデルの一つとなり ${ }^{1)}$ ，また消費者による自主的な環境保全型農産物の「買い支 え」という意味で, 今日の倫理的消費の源流の一つでもある.

この「産消提携」の消費者組織のルーツには, 1960 年代末に生活協同組合運動として草の根 的に広がっていた共同購入運動がある。加えて, 酪農事業家で著述家でもあった岡田米雄22)が,

* 本稿は 2018 年 6 月 2 日の経済学史学会第 83 回大会で行なった報告に基づいている。レフェリー並びに編 集委員の方からの大変有意義なコメントに感謝いたします，ただし残された間違いは全て筆者に属します，

1）例えば Henderson and Van En（2007, 258-59/訳 316-17).

2）岡田米雄（1914-没年不詳）。酪農事業家，著述家，社会運動家．自らの事業経験とマルクス『経済学・ 哲学草稿』の疎外論に触発され構想した「消費者と農民の自給農場」を基に, 1971 年から北海道のよつ ば牛乳の共同購入運動を都市部で組織化．この消費者組織の一つから派生した「安全な食べ物をつくっ て食べる会」と生産者を仲介し, 消費者による生産物/出荷物の全量引き取り, 生産者による価格決定 などの原則を取り決めた．よつ葉牛乳の消費者共同購入組織はその後, 複数の産消提携消費者ネットワー クの基盤となる．しかしいずれの組織でも自身の不透明な会計や独善的な指導により会を追われた（安 全な食べ物をつくって食べる会 30 年史刊行委員会 2005 ；岡田 1971).

『経済学史研究』 63 巻 1 号, 2021 年. (C) 経済学史学会. 
マルクスの疎外論に触発され「消費者と農民の自給農場」構想を発案, 組織化した消費者グルー プの一つは, 1973 年に千葉県安房郡三芳村の生産者と東京の消費者の提携組織（後の「安全な 食べ物をつくって食べる会」）となり，その後の産消提携の事業モデルに大きな影響を与えた.

一方, 1960 年代末の一時期この岡田と活動を共にし, その後自らが有機農業運動と「産消提携」 に携わる中で, 1978〜 79 年に運動理念としての「提携 10 か条」を提唱したのが一樂照雄である. 一樂は当時, 財団法人協同組合経営研究所理事長を勤め, 同時に 1971 年設立の有機農業研究会 (現 日本有機農業研究会，1976 年に改称）の創始者として，1970～80 年代の日本の有機農業運動に 大きな影響を与えた。それまで自然農法，無農薬農業，健康農法など様々な名称で呼ばれていた 農法を，ロデイル（Rodale 1945）の Organic Methodから 1971 年に初めて「有機農法」と訳し, 用いたのは一樂である3).

1971 年に有機農業研究会を設立する前の 1967 年頃から, 一樂は農業協同組合, 生活協同組合, 漁業協同組合など, 異なる分野の協同組合間での「相互の提携の強化」や「本質的立場の一体化」 （一樂 1967 b, 2-3）を模索していた ${ }^{4}$. 一方で, 1970 年前後から全国各地での有機農業と生産者 と消費者の直接的な結びつきに出会い，そこに自らが理想とする「協同原理による公正な社会」 に近い実践の形を見出す。1970～80 年代の日本の有機農業と「産消提携」は，岡田の「消費者 と農民の自給農場」構想による自然・人間疎外の克服の理念に加えて，一樂の協同組合思想，す なわち農と食を介した「相互扶助（自立互助）」と「家族の延長としての生産者と消費者」に基 づく「協同原理による公正な社会」の理念によって，資本主義市場経済へのオルタナティブ運動 として位置づけられた.

しかしこれまで，その影響と貢献に比して，一樂の社会経済思想の客観的な評価は十分になさ れてはこなかった。日本の有機農業の歴史に関する文献（久保田 2008 ; 栘潟 2008 ; 舘野 2012 ; Barton 2018）に扔いても，一樂の名は「提携 10 か条」などとともに記され，言及されているが, 有機農業や運動実践の側面からの紹介が中心である。 また原（2019）は，一樂が 1969 年前後に 提唱した「農住都市構想」と「農林省による農村住宅団地建設計画」について論じているものの, 都市計画の観点からの研究である。一方, 日本の協同組合運動先駆者である賀川豊彦と一樂を, 農民運動や協同組合による「社会改造」の提言者として比較，論評したものとして加山（2018） がある ${ }^{5)}$.ここでは一樂思想の概略が，一樂没後に農山漁村文化協会が編んだもの（1996a; 1996b；2009）を元に端的にまとめられ，賀川思想と一樂思想に共通する点として，資本主義経

3）このとき一樂は黒沢西蔵を訪ね，黒沢が設立した野幌機農学校の校名に使われた「機」の意味を聞きに 行っている．黑沢は「大自然運行の機」「天地の機」と答えている（黒沢 1971）。一樂が黒沢を訪問し た経緯と有機農業（農法）という言葉に込めた意味については, 福島土といのちを守る会・十周年記念 誌編集委員会（1991）および久保田（2008）も参照.

4）一樂による「協同組合間提携」の模索は，80 年代以降も続く(協同組合経営研究月報編集 $1982 \mathrm{a} ; 1982 \mathrm{~b}$ ).

5） 2017 年 11 月 4 日に山形県高畠町で行なわれた第 16 回「一樂思想を語る会」の講演原稿に部分的に加筆 されたもの．賀川と一樂はともに 1958 年 1 月の ICA（国際協同組合同盟）の第一回アジア会議（クア ラルンプール）に出席，その時の搭乗の様子が写真に残っている（加山 2018）. 
済体制への批判, 協同組合による社会改造の重要性, 運動が組合員による「下からの運動」であ ること, 農業者の農産物の生産は自らの食（いのちとくらし）のためであり商品（モノ）として するのではないこと, などが挙げられている，また両者の差異として，一樂の資本主義経済体制 への批判が賀川ほど構造的でないこと, 賀川のような「防貧としての協同組合運動」としての社 会的意識が一樂には見られないこと，なども指摘されている。しかしこれらは，一樂自身による 元論文には記述されているものがあり，加山（2018）が講演用原稿であることもあって一次テキ ストを用いた検討としては十分ではない.

特にこれらの既存研究では, 一樂思想のもつ経済学的な側面, また戦前の産業組合からの影響 を受けた自らの協同組合思想に基づき，なぜ一樂が 1970 年代以降の産消提携運動を支持したの か, 加えて一樂による産消提携運動の経済的側面の評価については十分に議論されていない.そ の理由として，一樂がアカデミズムに所属する研究者でなく協同組合を中心とした実践家であっ たこと，その論文や対談等が主に一般の言論誌でなく，一樂が勤務した複数の協同組合組織の月 報（『協同組合経営研究月報』協同組合経営研究所）や自身が立ち上げた日本有機農業研究会の 機関紙（『土と健康』）などに掲載されていたこと, さらに一樂の評価が主に有機農業運動や協同 組合分野からのものが中心だったこと，などが挙げられるかもしれない.

\section{II 一樂の業績と思想の系譜}

\section{1. 一樂の経歴と業績}

一樂は, 1906 年に徳島県で父, 自小作農家の田村与平の三男として生まれた6).小学 5 年生の ときに伯父一樂善藏の養子となり, 一樂姓となる7). 養子先の一樂家は木炭・油・穀物・塩・雑 貨などの卸兼小売商を営んでいた。一樂は, その家業において計量升に入れる客用の米を隙間を 残し升面を削り取らんばかりにならす様子を見て, 小・中学校のころから商売に対する嫌悪感を 覚えていたという（農山漁村文化協会 2009, 355-57）。また自身が「世直し」についての執念の ような感情をもちつづけたのは，信心深い祖母の影響だと後に回顧している（ibid., 363-65）.

その後, 1930 年に東京帝国大学農学部農業経済学科を卒業, 在校時は農業経済学者の佐藤寛 次 ${ }^{8)}$ と那須皓9) に師事した，那須からは「農政学」，佐藤からは「農業経営学」と「産業組合論」 の講義を受け,「なかでも佐藤教授の産業組合論の講義は楽しく, 熱心に勉強もした」と回想し ている（農山漁村文化協会 2009, 357）。一樂が産業組合中央金庫を志望するきっかけとなった産

6）一樂照雄の養父が一樂善藏, その善藏の弟の与平が一樂家から田村家へ養子に行き, 照雄はその田村与 平の三男. 農山漁村文化協会 $(2009,354)$, 㧍よび一樂の長男信雄氏から四男重雄氏経由の聞き取り（2019 年 8 月 22 日）による.

7）農山漁村文化協会（2009）の卷末略歴・関連事項年表.

8）佐藤寛次 $(1879-1967)$. 著書に, 佐藤 $(1918,1936)$ など.

9）那須皓（1888-1984）. 著書に, 那須・東畑（1932）など. 
業組合関係の団体などへの現地見学を企画したのが佐藤で，また一樂が産業組合中央金庫を志望 していることを知らずに, その就職を農林省の農務局長石黒忠篤に依頼したのが那須である (ibid., 357-59)。このとき一樂はこの那須による就職斡旋を断っている。ささらに佐藤は, 1934 年に結婚 した一樂 (ibid., 374, 406）の仲人も務めた ${ }^{10)}$.

卒業後の一樂は, 戦前の産業組合中央金庫および戦後の農林中央金庫に勤務したのち, 全国農 業協同組合中央会の理事や協同組合経営研究所理事長などを歴任した。また協同組合経営研究所 理事長在職中に，民間団体である有機農業研究会を設立し，日本の有機農業と産消提携運動に指 導的立場から関わった。

「農業を中心とした社会経済改革の実践者」としての一樂の業績は二つある。一つは協同組合 経営研究所理事長の在任中の 1971 年に, 日本で初めての有機農業に関する研究・啓蒙団体であ る有機農業研究会を仲間とともに立ち上げたこと, もう一つはこの有機農業研究会の 1978 年の 年次大会にて，「提携 10 か条」を「産消提携」運動の理念として提唱したことである.

一樂はこのような事業と運動の傍ら，戦前の産業組合中央金庫勤務時代より，協同組合関連の 雑誌への著述や，自らが主宰するシンポジウムや座談会等の司会としての発言の記録を, 1930 年から亡くなる 1994 年までの 60 年超にわたり 100 編以上残している.

その主なものとして，1974 年には当時の有機農業のテキストであったPay Dirt（Rodale 1945） を『有機農法一自然循環とよみがえる生命』として自ら翻訳, 有機農業の普及に努めた. 加えて 1967 年には一樂の主導で, 1966 年の第 23 回国際協同組合大会（ウィーンで開催）にて採択され た「協同組合原則に関する委員会報告」（International Co-operative Alliance [1966］1967）を，全 国農業協同組合中央会・全国漁業協同組合連合会・日本生活協同組合連合会との合同で『協同組 合原則とその解明』として翻訳・編集している（全国農業協同組合中央会ほか 1967）。また 1968 年には, The History of the Rochdale Pioneers（Holyoake [1893］1900）を，協同組合経営研究所訳 で『ロッチデールの先駆者たち』として出版した。一樂はこれらの出版物に対し，それぞれ「訳 者あとがき」や「解説」を残しており，例えば『協同組合原則とその解明』では，本位田祥男ら 協同組合研究者や当時の生協理事らを集めた討論会を主催し，1966 年版の ICA 協同組合原則へ の評価とその議論の記録が「報告書をめぐる討論」として記載されている．また 1968 年に全国 農業協同組合中央会等 3 組織の代表と出版した『協同組合とは一新しい協同組合原則の解説を中 心にして』（手島ほか 1968）の最終章には，一樂が生涯掲げる「自立・互助」の文言とともに, 一樂の目指す協同組合運動のあり方が経られている.

一樂はその後の 1967〜 70 年にかけて，自らの協同組合思想とその実践に関する論考を続けて 発表, その実現のため「農住都市構想」を発表した（一樂 1968, 1969）。しかし実施にあたった 農協がこの構想を農家の資産管理（相続税）対策と解釈したため, 構想は一樂の新たな地域社会

10）一樂の長男信雄氏へのインタビュー（2019年 9 月 5 日）による。なお，信雄氏所有の一樂の結婚式の 集合写真には新郎の一樂と仲人の佐藤が並んで写っている. 
建設の理想とは程遠いものになったという（農山漁村文化協会 2009, 230-31）。一樂は既存組織 での理想実現の限界を感じたと推測される，直後の 1971 年に一樂は, 前述の岡田米雄らととも に自主的な「ふるさと生活協同組合」運動の実践に奔走，しかし，これも資金が続かず出資者も 集まらなかったことからその年のうちに解散した（露木 1982, 413-14 ; 安全な食べ物をつくって 食べる会 30 年史刊行委員会 2005,32$)$. 理由は事業継続のための経済的基盤の欠如に求められよう. 一樂はその後, 自らの理想の実現からいったん離れ, 社会問題となり始めていた農薬や食品公害 の問題に対処するため, 研究者・医者らとともに 1971 年に有機農業研究会を設立する. このと き日本各地では, 有機農産物生産者自身による消費者との結びつきや, 岡田が「ふるさと生活協 同組合」運動失敗後に自ら組織化を試みた都市消費者の農産物の購入グループなどが出てきてい た. 一樂は, 有機農業研究会での活動を通してこの「有機農産物生産者と消費者の直接的なつな がり」(後の産消提携) に出会い, そこに自らの協同組合の理想の形を反映していくことになる.

\section{2. 一樂の著述の特徵と社会経済思想の系譜}

一樂の著述のうち，主に一樂が所属した各団体機関紙等に 1930～84 年に発表した論文・論稿 27 本は, 抜粋・転載されて『協同組合の使命と課題』（一樂 1984b）としてまとめられている. また一樂没後の 1996 年 1 月に一樂を知る関係者で構成された「一樂照雄伝刊行会」によって,『一 樂照雄伝』（農山漁村文化協会 1996a）がまとめられた.この『一樂照雄伝』はさらに同年 3 月に, 『暗夜に種を播く如く一樂照雄伝 普及版』（農山漁村文化協会 1996b）として刊行された ${ }^{11)}$. こ れは，「一樂運動論の立脚点を明らかにしたいため」，その「基本的な考え方を示す部分を丹念に 選択し編集したもの」（農山漁村文化協会 2009，15-20）であり，一樂の著述からの抜粋のほか, 一樂の略歴・関連事項年表, 関係者による若干の時代背景の解説, さらには一樂自身とその妻に よる生涯の回顧録も掲載されている.

これらは, 一樂の思想とその生涯を知るためのいわば入り口であるが, まとめられた論稿やそ の抜粋から一樂自身の思想のエッセンスは把握できるものの, これらのみでその著述の時代背景 や他の社会思想からの影響を把握することは難しい. なぜなら一樂の論稿には一切引用脚注がな く, また根拠となる思想体系等もほとんど記されていないからである. しかし，一樂の 60 年超 にわたる著述や多くの対談の記録を，その刊行時の全文を用いて同時期の他の協同組合思想や社 会運動家の著述と丁寧につき合わせて読むと, そこには一樂が影響を受けたと思われる思想家, 当時の社会経済運動と思想的背景, さらにはそれらと共通する文言などが散見され, 一樂の著述 との関連を読み取ることができる.

それらの著述によれば, 成人後の一樂の社会経済思想の変遷は, その所属機関および主張によっ て 4 つの時代, すなわち, 戦前の産業組合中央金庫勤務時代（1930４5 年), 戦後の農林中央金

11）農山漁村文化協会（1996a；1996b）は，13 年後に『暗夜に種を播く如く一樂照雄一協同組合・有機農 業運動の思想と実践』（農山漁村文化協会 2009）として復刻された. 
庫時代（1945～58 年）および全国農業協同組合中央会時代（1958～65 年), 協同組合経営研究所 時代（1965～71 年), 有機農業研究会創設と産消提携運動時代（1971～94 年）に区分される.ま た思想的系譜としては，主に 4 つの系譜からの影響が見られる。第 1 に，協同組合思想（日本の 戦前の産業組合思想，戦後の国際協同組合同盟の諸原則， R. オーウェン，イギリスのロッチデー ル公正先駆者組合，賀川豊彦）および昭和恐慌期の農本思想，第 2 に，日本各地における有機農 業運動や社会活動の実践者との交流（黒沢西蔵, 梁瀬義亮 ${ }^{12}$, 岡田米雄, 高松修13), 山形県高畠 町有機農業研究会など), 第 3 に, E. F. シューマッハーによる農業観と経済学批判, 第 4 に, 1970 年代前後の環境・農業思想（レイチェル・カーソンなど）である.

このうち第 1 の戦前の産業組合思想とその時代背景が, 一樂の生涯にわたる「協同組合による 公正な社会」の理想と「提携 10 か条」に大きく影響している. 特に, 一樂が繰り返し主張する「公 正な社会」（弱者を救う）の実現と，そのための「家族・地域的な共同体」を基盤とした「倫理」 の必要性の源流となっている．また産業組合中央金庫勤務時代に経験した「産業組合拡充」運動 下での標語「自力更生・隣保相助」は，一樂の協同組合思想の根幹「自立互助」となる．さらに 1966 年版協同組合原則をめぐる討論会での一樂の発言，経済合理性や資本・国家権力とは異な る「相互扶助（弱者を救う隣保相助）」に依拠した「民衆自治の場」の必要性（全国農業協同組 合中央会ほか 1967 ；一樂 $1967 \mathrm{c}$ ） は，その後の「提携 10 か条」の原型となった，加えて昭和恐 慌期の農本思想, 中でも岡本利吉の『規範経済学』（1929）およびその「共働運動」との共通点や, 平實の『産業組合の基礎理念』（1941）と「提携 10 か条」の文言の類似なども見られる．ただし 一樂の著述に岡本利吉と平實の名は見られず，その思想的影響を断定することはできない.

一方，第 2 の思想的系譜として挙げた岡田米雄の「消費者と農民の自給農場」構想と，岡田が 事業として仕掛けた北海道の「よつば牛乳共同購入」の消費者ネットワークは, 実際に各地の産 消提携運動を支えた消費者グループの基盤となった．さらに岡田が 1973 年に起草した東京の産 消提携グループ「安全な食べ物をつくって食べる会」の趣意書とその実践方法は，一樂が 1978 年に「提携 10 か条」を作成した際の運営方法として参考にされた。また, 第 3 のシューマッハー は，一樂自らが最も感銘を受けた思想家の一人として挙げており（一樂 $1980 b ; 1980 \mathrm{c}$ ），脱物質 的成長, 市場価格への批判, 景観・健康・文化・農業者への支払いへの考慮の必要性などは, 後 の一樂の主張に繰り返し現れてくる.さらに第 4 のレイチェル・カーソンも一樂自身が最も影響 を受けた著述の1つとして挙げられている（一樂 1980b）.

12）梁瀬義亮（1920-1993）．奈良県宇智郡五條の医師．有機農業研究会設立人の一人１959 年に，「農薬の 害」に関するパンフレットを発行（梁瀬 1978, 111-12），世界に先駆けて農薬の害に警鐘を鳴らした. その後, 農薬の害に苦しむ患者らととともに, 自ら無農薬農産物によって健康を守る会である慈光会 を立ち上げた（梁瀬 1975 ; 慈光会サイト http://www.jiko-kai.org/about/profile.html）.

13）高松修（1935-2000）。東京都立大学工学部助手，日本有機農業研究会常任幹事．環境運動家．岡田米 雄が仕掛けた「産消提携」グループ「たまごの会」設立にかかわる（高松 2001）. 


\section{III 一樂の社会経済思想の概要}

\section{1. 一樂の「提携 10 か条」}

生涯にわたり一樂が掲げた協同組合思想による理想社会は，以下の 5 点にまとめられる. （1）協同原理による公正な社会と「自立互助」，(2）農業の建て直しと商業/流通資本からの独立, （3）農産物の「商品性からの脱却」，（4）生活の商品依存からの脱却（消費者の自主性と学習）と 手づくり（食べ物・娛楽・働く喜び，（5）実践としての「生産者と消費者の提携」である.

このうちの (5)の運動理念の原則として, 1978 年の有機農業研究会の年次大会にて一樂が発表, 翌 1979 年に同研究会の機関紙『土と健康』に掲載されたものが, 前述の「提携 10 か条」(一樂 1979）である。この「提携 10 か条」は以下で構成される（以下は筆者の要約，詳細は下記引用 参照)．第 1 条：生産者と消費者の人と人との友好的付き合い関係，第 2 条：生産者による計画 的な生産，第 3 条：全量引き取り（消費者の食生活はできるだけ全面的にこれに依存），第 4 条： 生産者・消費者相互の考慮による価格の取り決め, 第 5 条：相互理解の努力と双方のメンバー各 自が相接触する機会，第 6 条：生産者グループまたは消費者グループによる運搬，第 7 条：民主 的な運営と相互扶助的な配慮, 第 8 条: 学習活動の重視, 第 9 条 : 適正規模の保持（地域の広さ とメンバー数を適正にとどめて，グループ数を増やし互いに連携), 第 10 条：現状は不十分でも 発足後逐次相ともに前進向上, である.

このなかで特に，一樂が重視していた項目は，第 1 条の生産者と消費者の「人と人との友好的 付き合い関係」である。いわゆる今日でいう「顔の見える関係」の倫理的側面とそれを可能とす る組織運営方法を規定したものと考えられる.

生産者と消費者の提携の方法について（「提携 10 か条」）

一．生産者と消費者の提携の本質は，物の売り買い関係ではなく，人と人との友好的付き 合い関係である。すなわち両者は対等の立場で，互いに相手を理解し，相助け合う関 係である，それは生産者，消費者としての生活の見直しに基づかねばならない．

二，生産者は消費者と相談し，その土地で可能な限りは消費者の希望する物を，希望する だけ生産する計画を樹てる.

三．消費者はその希望に基づいて生産された物は，その全量を引き取り，食生活をできる だけ全面的にこれに依存させる。

四. 価格の取り決めについては, 生産者は生産物の全量が引き取られること, 選別や荷造, 包装の労力と経費が節約される等のことを, 消費者は新鮮にして安全であり美味な物 が得られる等のことを十分に考虑しなくてはならない.

五. 生産者と消費者とが提携を持続発展させるには相互の理解を深め, 友情を厚くするこ とが肝要であり，そのためには双方のメンバーの各自が相接触する機会を多くしなけ 
ればならない.

六．運搬については原則として第三者に依頼することなく，生産者グループまたは消費者 グループの手によって消費者グループの拠点まで運ぶことが望ましい.

七. 生産者, 消費者ともそのグループ内においては, 多数の者が少数のリーダーに依存し すぎることを戒め，できるだけ全員が責任を分担して民主的に運営するよう努めなけ ればならない，ただしメンバー個々の家庭事情をよく汲み取り，相互扶助的な配慮を することが肝要である.

八. 生産者および消費者の各グループは, グループ内の学習活動を重視し, 単に安全食糧 を提供, 獲得するだけのものに終らしめないことが肝要である.

九. グループの人数が多かったり, 地域が広くては以上の各項の実行が困難なので, グルー プ作りには, 地域の広さとメンバー数を適正にとどめて, グループ数を増やし互いに 連携するのが，望ましい。

十. 生産者および消費者ともに, 多くの場合, 以上のような理想的な条件で発足すること は困難であるので，現状は不充分な状態であっても見込みある相手を選び発足後逐次 相ともに前進向上するよう努力し続けることが肝要である.

(一樂 1979, 2-6より「10 か条」部分を抜粋)

「提携 10 か条」は, 一樂が主催する有機農業研究会内の「提携問題研究委員会」において, 1978 年 9 月と 10 月に, 有機農業生産者, 消費者提携グループ代表, 一樂ら研究会幹事など 15 名が集まって議論し，その意見を一樂ほか 2 名が取り纏め，第四回全国有機農業大会に問題提起 として提案された（一樂 1979, 2, 6). 各原則のうち第 2 条以下の提携方法や組織運営に関するも のの一部には，例えば岡田が手掛けた「安全な食べ物をつくって食べる会」での「生産物全量引 き取りの原則」などが基となっているものがある。しかし，一樂が特に重視していた第 1 条や, 第 7 条，第 8 条，第 9 条は，一樂自身の協同組合思想，特に戦前の「産業組合主義」や前述の一 樂による「1966 年版協同組合原則」についての「報告書をめぐる討論会」（全国農業協同組合中 央会ほか 1967）での発言がその原型であり，また第 5 条，第 6 条にも，一樂が強く主張する「提 携において生産者と消費者が顔を合わせた知り合い」になることの重要性が強調されている.

以下では，この「提携 10 か条」の基となっている一樂の社会経済思想を先の（1）（4）に分け て紹介したい.

\section{2.一樂の社会経済思想}

（1）協同原理による「公正な社会」と「自立互助」

一樂の生涯を通じての主張は「協同原理による公正な社会」の実現であった，一樂にとっての 「公正でない」社会とは, 資本主義における「力づくの世界」, すなわち「力の強い者が弱い者を 犠牲に」する，「正直者が損をする」関係であり（一樂 $1967 \mathrm{c}, 9 ; 1972,21 ; 1973,14)$ ，ここでの「力 
の弱い者」「正直者」とは, 経済的に不利な立場に置かれ, 一樂によれば「自主的に発達したの ではない」（一樂 1959a, 26; 1959b. 15）農業者のことである.

公正でないということの内容は何かといえば, 結局力づくの世界です. 力の強い者が弱い 者を犠牲にしていく, 征服していく, 弱肉強食の世界だ。これが資本主義の基礎になって いますが, とにかく弱肉強食, 強い者勝ち, そして銘々は自由勝手に競争する, 自由勝手 に競争するから強い者勝ちになる．これが許される倫理になっている．そういう倫理感に たっての経済組織あるいは経済関係を力の及ぶ限り打破して，公正なる社会を実現するこ と, すなわち, いくらかでも, 強い者は弱い者を労わり助けていく相互扶助, この関係, そして横着者が得をして正直者が馬鹿をみる, こういう不公正な関係を除去して, 横着者 が得をしない, 正直者が損をしないという経済分野を建設していくことが協同組合の目的 でなければなりません。

(一樂 1973, 14)

一樂によれば, 日本の農業は, 農業内部から自然に発展して交換経済に入ったのではなく, 農 業以外の利益のために政府が農業者を植民地的に扱うことで, 交換経済に不当に追い込まれた。 資本主義社会が成り立つためには，その周囲に植民地的奴隷的待遇に甘んじるものがなければな らないが, 日本には植民地がなく, 地租や, 煙草の専売制度, 酒の自家醸造の禁止などの農業者 の自由の制約によって, 農民が植民地の役割をさせられた。すなわち産業資本の発達の過程で, 農業は交換経済，商品経済のなかにまき込まれた。農業者は，このような植民地的な経済外的な 収奪からのがれ，自由を獲得する必要がある（一樂 1959b, 14-18）。また農業は（農業に対して 植民地的な収奪を行ってきた）国家から解放され, 他の経済界と対等の立場を築くことが必要で, それが協同組合農業の使命である（一樂 $1967 \mathrm{c}, 12$ ). 同時に「社会的公正さを維持する」ために は，農業者だけではなく，消費者教育と組織化の奨励が必要だが（一樂 1964, 40), 農民と消費 者の間も壁で分断されてしまっている（一樂 $1966 \mathrm{a}, 2)$ ）消費者も，メーカーが次々と新商品を 販売する中で, 主体性を喪失している（一樂 $1967 \mathrm{a}, 2$ ).

この「公正な社会」実現のために, 一樂は協同組合の役割, 協同原理の必要性をくり返し主張 する．協同組合とは，「自立・互助による結合態勢」であり，「自立の精神を前提として，おたが いに助けあ」う「前進してゆく‥生きた有機体」である（一樂 1959a, 18）．協同組合の目的は, 「弱 肉強食を常道とする資本主義の特徵」を不公正と認識し（一樂 1972, 21）,「強い者は弱い者を労 わり助けていく相互扶助」によって「正直者が損をしないという経済分野を建設」することであ る（ibid., 21；1973，14）。そのためには，切り離され孤立した存在としてそれぞれが利益を追求す るのではなく, 社会的に共存共生する存在として, お互い手を携え, 連帯して公正な関係を実現 しょうというのが協同運動の目的・趣旨である（一樂 1976, 24）.

一樂はこの協同原理による公正な社会実現のために, 1966 年版の ICA 協同組合原則から以下 を引用し，教育の必要性を訴えている（一樂 1973，18）。「経済制度を協同組合原則を基礎にして 
再編成する努力は，個人企業あるいは国家企業のそのいずれとも異った訓練を必要とする．協同 は相互扶助の一形態として，利己的または自己本位の衝動，あるいは人為的権威への服従とは別 の動機に訴える，集団的な自己訓練は野性的なもの，または自己繁殖するものではなく，育成さ れるものである」(全国農業協同組合中央会ほか 1967, 69-70) ${ }^{14)}$.

人間は本来一人一人が切り離され孤立した存在ではなく, 社会的に共存共生する存在であ ります。それが，資本主義の発達に伴って，競争社会を形成し，弱者はますますしいたげ られ，正直者が馬鹿をみる，弱肉強食の傾向が進んでいます，‥各個人がめいめいの利益 を追求するのでなく，公正な関係をつくりあげて行くことを，お互い手を携え，連帯して 実現させようというのが, 協同運動の目的であり趣旨であります.

(一樂 1976, 24)

（2）農業の建て直しと商業/流通資本の支配からの独立

このような協同原理による「公正な社会」の実現のため, 一樂は,「農業の建て直し」を「工 業の論理」とは別の論理に基づいて行う必要があると主張する(一樂 $1980 \mathrm{a}, 56$ ) ${ }^{15)}$ 。一樂によれば, 近代化し，進歩発展したのは農業ではなく，農業に関連する農業機械や肥料・農薬，温室資材な どの工業とそれを流通させる商業であり（一樂 1973, 23；1975a，23）, 資本力による自由競争，す なわち「大は小を征服して…寡占・独占化する工業の論理」が零細家族経営の農業に持ち込まれ た（一樂 $1975 \mathrm{a}, 24)$ 。「工業の論理とは別の論理」とは, 農 (水) 産物を「市場経済の外に存在さ せると共に，生産・消費両者の意識において商品という観念を払拭させること」(一樂 $1980 \mathrm{a}$, 58），すなわち「食糧についての脱商品性」（一樂 1977, 2) である。一樂が農産物（食糧）を商 品としてはならないと主張する理由には, 第 1 に, 食糧は他のものに比べて絶対的に必要である こと（生存権や生活のミニマム）（中村・一樂 1983, 50), 第 2 に，日本の農業全体と漁業の大部 分は資本主義的産業ではなく零細家族経営で生産されていること（一樂 $1980 \mathrm{a}, 55$; 中村・一樂 1983，50），第 3 に，流通過程が商業/流通資本に握られ，農家自ら価格を決められないこと（一 樂 1966b, 26-28; 1973, 24; 1980a, 55-56), の3 点が挙げられる.

このうち 3 つめ「農家自らが価格を決められないこと」とは, 政府による米の買い取り, 中 央卸売市場における生産者不在での仲買い人と買い手による青果物の価格決定, 同じく中央卸売 市場の交渉における生産者と商人の対等でない立場などから（一樂 1966b, 26-27）,「生産過程が

14）原文は以下の通り。“7. Education: ... The effort to reshape the economic system on the basis of Co-operative principles requires a different discipline from those of either individual or governmental enterprises. Cooperation as a form of mutual aid appeals to other motives than man's selfish or self-regarding impulses or obedience to duly-constituted authority. Collective self-discipline is not a wild or self-propagating, but a cultivated growth." (International Co-operative Alliance [1966] 1967, 34)

15）工業製品と農 (水) 産物について「同一に貨幣価值だけで一律に論じるようなことはやめて, 経済学の 対象にするなら基本的に別な論理をもってこないといけない」(中村・一樂 1983, 44). 
直接に産業資本によって占められるのではなくその下請的な地位」にあり, 生産者自身が, 価格 決定を含めて，自らの生産物の流通に関与できていないことを意味する（一樂 1980a, 55-56）. そのため需要供給の動向や品質を反映させる合理的な取引になりがたく，農業が他の企業や政府 に隷属したままでは, 価格の要求, 陳情や運動を重ねてもその効果は臨時的かつ部分的である（一 樂 1966b, 28). 食料品が, 必要以上に商業/流通資本の道具にされており, 儲けるための商品販 売という観念によって，中間資本に牛耳られ，生産者も消費者も資本にふりまわされている（一 樂 1973, 24-25).

生産過程が直接に産業資本によって占められるのではなくその下請的な地位に在り, 流 通過程が流通資本に握られているのであるから，生産者と消費者とが提携して，直接的に は商業資本の支配から脱出し, 間接的には産業資本から独立することを目指しての闘いは, 協同組合運動としては恰好な活動である.

農産物は人間にとって最も重要な物資であるにもかかわらず，その需給関係が常に不安 定であり，価格が暴騰と暴落を繰り返している，農民は儲けることを目的に生産している が，自らは売り值に関与することもできない．消費者は安く買えることを望んでいるが生 産者の手取り金額の何倍という高值を払わねばならない．余りにも莫大な中間経費を要し ているが，だからと言って個々の中間業者が暴利をむさぼっているのではない，今日の流 通機構の中においては如何ともすることのできない不可避の現実なのである. その不合理 は, 価格問題だけではなく, 生産の仕方と消費の仕方の双方が共にまことに好ましからざ る形にさせられているという事実が重大である.

(一樂 1980a, 55-56)

同時に，農民（生産者）が主体的に農業の問題を考えるために，中央卸売市場などを経由した 地域分担による適地適作の単作主義ではなく，多角栽培と地場生産・地場消費することが奨励さ れる，その土地の気候風土の許す限り，あらゆる農産物の栽培をし，地場生産・地場消費をでき るだけ尊重することにより，1）遠方輸送による運送会社のいたずらな儲けや包装資材の濫費を 排除，2）鮮度を落とさない，3）消費者と生産者の立場の相互理解，が可能となる．そのことが, 流通資本の入る余地を少なくし，後述するように，生産者による農産物の「贈与」と消費者によ る「お礼」という関係を成立させる適当な形態となるという。一樂はこれを，「素朴なる流通形 態を回復」することと言い換えている (一樂 1973, 24-25).

（3）農産物の「商品性からの脱却」と「提携」の関係

農産物の「商品性からの脱却」の特徵は，生産者と消費者の関係性から 4 点にまとめられる. 第 1 に，農産物は交換価值ではなく使用価值で評価されるべきであること，第 2 に，農産物の金 額は不特定多数で構成される市場を通じずに，直接「顔を合わせて」当事者同士で自由に決定す ること，第 3 に,「提携」での生産者と消費者の間の生産物の提供と金銭を通じた代償と謝礼は, 
形としては「取引」,「物の代金」であっても，実質は「贈与とお礼」であること，第 4 に,「提携」 での生産者と消費者の関係は，取引の相手ではなく，「家族の延長として…親戚や友人以上に苦 楽を共にする相手」であること，である（一樂 1980a, 55-58；中村・一樂 1983，43-44, 50-51， 55)。これらはそのまま前述の「提携 10 か条」第 1 条の「生産者と消費者の提携の本質」の説明 に記されている（一樂 1979, 2-3）.

物を交換価値で評価しないで使用価値で評価する．金銭の授受は形としては物の代金で あっても実質は代償と謝礼である，だからその額も市場で形成され常に変動する必要がな く，当事者同士で自由に決めることができるし，固定させることもできる．品物について は形や色よりも安全性や味によって評価され，その取扱いに選別，包装，荷造りなど，商 品流通としては一般に極めて重要なことが，ほとんど不要である．要するに，お互いの心 組としては，相手を取引の相手と見るのでなく，家族の延長として普通の親戚や友人以上 に苦楽を共にする相手と見るのである.

(一樂 1979, 3)

第 1 の「農産物は交換価值ではなく使用価值で評価」の意味は，「提携 10 か条」第 1 条の説明 にあるように，直接的には「品物については形や色よりも安全性や味によって評価」（一樂 1979, 3）することを指す。一樂によれば，農業は，金儲けのためではなく，うまくて健康によいもの をつくるためのものである (一樂 1973, 21-22). 生命は金銭より大切で, 幸福は金銭では必ずし も買えず, 安全は便利さより尊い(一樂 1979, 3). すなわち食糧品は工業製品とは本質的に異なり, 人間の生命にとって必須なもので（中村・一樂 1983,44），交換価值の尺度からすれば大きな部 分を占めないのが現状だが，使用価值からすれば他のあらゆる商品には比べられないほど重要な 物である（一樂 $1980 \mathrm{a}, 55)$ ，一方，例えば経済成長の根拠となっている付加価值は，使用価值に 価值があるからではなく, 交換価值として利潤が発生し，その利潤が増えたため付加価值が増え たとする（中村・一樂 1983，46）。一樂は，農産物（食糧）が持つ金銭評価できない特質と，農 産物生産の市場取引での「儲け (利潤)」の否定の 2 点から, 農産物の「使用価値」での評価を 主張するのである.

実際に一樂は，1989 年，農水省が有機農業に対し「高付加価值農業」という名称をつけて予 算計上しょうとしたことに猛抗議し，当時の大蔵省主計局に申し入れを行っている（福島土とい のちを守る会・十周年記念誌編集委員会 1991，64-79)。その理由として，補助金政策による農業 保護は農業をだめにすること（農山漁村文化協会 2009, 323-24），また農水省が「にせ物・まが い物をひっくるめて有機農業」と考えて「高付加価值型農業」という言葉を使っており，付加価 值を高めることが「より高く売れる」という意味にとられること（『現代農業』編集部 1989, 178），を挙げている。一樂によればこの申し入れにより，予算の用途は農水省による有機農業の 奨励や指導にではなく, 調査予算となったという（農山漁村文化協会 2009, 323-24）.

第 2 には, 農産物の「值段」の決め方についてである。これには, 商業資本管理のもとではな 
く「当事者」間で金額に合意すること，および「顔を合わせて $[の]$ 知り合い」すなわち「直接 的かつ継続的な関係」による不正の抑制, が挙げられる。

前述のように, 流通過程が商業/流通資本に握られ, 中央卸売市場などでは農家自らが自分の 生産物の価格を決められない。しかし, 生産者と消費者の「提携」における農産物の金額は,「商 業資本の管理のもとに形成される值段ではな」く，「農民が決めた值段」で,「当事者の片一方が 言いだし，片一方がそれに同意して決めた值段」だという．同時に「提携」では，売り手と買い 手が「顔を合わせての知り合い」, すなわち「対面」になっている．例えば，不特定多数を対象 とする市場経済においては，売り手はできるだけ高く売りたいと思うが，買い手と「対面」する 生産者は, 価格決定を消費者から任されたとしても, 高く売りすぎてはいけないと控えめになり， 両者の間で値段は問題にならないとされる（中村・一樂 1983, 54）.

この「対面」による抑制は, 価格だけでなく農産物の生産事情の共有にも当てはまる。例えば, 生産者がリンゴの農薬使用について, 無農薬ではできないので農薬を使用したが従来の散布回数 より大幅に減らすことができた，と消費者に伝えて了解をとり，生産者がその通りに実行したな らば，それは不正ではない，「生産者と消費者が直接に接触する場合はウソをつく必要はない」 と一樂は説明する（『現代農業』編集部 1989, 180）.

加えて, 一樂が, 生産者と消費者の「提携」が「商品性の脱却, 商品性の否定」の思想だと主 張する理由は，提携を通じた金銭の授受は形としては「物の代金」であっても，実質は両者間で の「贈与とお礼」だというものである.

一樂によれば，生産者と消費者が直接に取引して中間経費を省く「産地直送（産直）」のよう な流通方法は, 日本でも戦前から存在していた。市場経済においては, 売り手は不特定多数の買 い手に高く売ろうとする。産直においても，中間利潤や中間経費が不要になるならば，買う方は その分を安く買おうとし，売る方も高く売れると思うが，実際には思ったようにはいかない，し かし，有機農業と「提携」に拀いては，「いい品物を欲しい，有害でないものを作ろうという人 間的な理解と協力によるもののうえに流れる品物」で,「提携」は「商品性の脱却, 商品性の否定」 の思想だと主張する（中村・一樂 1983, 53-54）。このような「当事者間の同意による值段」は, 資本主義機構以前にあった前資本主義的時代の商品と同様のもので, 例えば「職人の芸に対する 注文生産」のようなものだという。したがって「提携」における生産者と消費者の関係は, 貨幣 経済であることは確かだが, 品物の值段は市場価格ではなく,「贈与経済の中の贈与に対するお 礼」，「貨幣によるお礼」である，なぜなら，これらは市場を通さず，交換価值を尺度とする交換 の意味でもないからだと主張される（ibid., 54-55）。ちなにここでの「贈与」とは, 生産者か らの「使用価值」の提供で（ibid., 54-55），提携を含めて農産物は，農民がまず自分が消費する ために農産物を作り，余った分を土地を持たない者（消費者）に贈呈するものである，一方の消 費者による「お礼」は, 継続して無料贈呈された消費者がお礼をしないわけにはいかなくなる（一 樂 1973, 22 ；現代農業』編集部 1989, 180）というもので,「品物を持っていない消費者」が「貨 幣価值」で支払うお礼だという（中村・一樂 1983，54-55）。したがって，生産者と消費者の提携 
における物と金銭のやりとりは「取引」ではなく（『現代農業』編集部 1989, 180），「貨幣価値を 尺度としての交換」でもない，というのが一樂の主張である（中村・一樂 1983, 55）.

にせ物であるか本物であるか，そういうことが問題なのは，その物が商品として取扱われ る場合の問題です，私たちが奨めているのは，農産物は商品としないことなんです，農家 が作った物は先ず自家で消費して，余ったものを消費者に提供するという関係なんです. 提供の方法は，売るのではなくて，形は売るのであっても本質は贈与なのです．それに対 しては貴った人からの謝礼が行なわれるのが当然でしょう．生産者と消費者の間では，売 買取引ではなく，贈与と謝礼の関係，提携の関係が生まれるのです.

(『現代農業』編集部 1989, 180)

さらに一樂は，このような「顔を合わせての知り合い」すなわち「対面」になっている生産者 と消費者の関係は，不特定多数を対象とした「市場」での取引ではなく，「家族の延長として」 の「苦楽を共にする相手」だとみなす。

前述のように，「提携 10 か条」第 1 条には，「提携」での生産者と消費者の関係として，「お互 いの心組としては，相手を取引の相手と見るのでなく，家族の延長として普通の親戚や友人以上 に苦楽を共にする相手と見る」とある。そのような付き合い関係を維持するため，生産者と消費 者の双方が，相手の立場を十分に理解すること，対等の姿勢を崩してはならないことが説か れ ${ }^{16)}$, その前提として, 競争心理に駆り立てられ, 他人のことが眼中にない今日の社会の傾向へ の反省が促される，そのため提携 10 か条の一樂による説明には，この生産者と消費者の相互理 解と関係維持, さらにそのための「顔を合わせて話す」ことの効果が, 繰り返し記される. 第 5 条「互いに相手の立場を理解する」，「相信頼する」ために「顔と顔を合わして話す機会を持つ」, 第 6 条「生産者グループまたは消費者グループの手によって…運ぶ」,「運搬の都度…顔を合わす」 ことが「互いに親近感と責任感を強める」などである（一樂 1979）.

のちに一樂は，産消提携における双方の立場の理解と協力という「有機的人間関係の成立」の 説明として，「人間性を生かして，人間と人間がフェイス・ッー・フェイスで会えば人情なりが でてくる」と述べている（中村・一樂 1983, 51）。この「フェイス・ッー・フェイスの人情」に もとづいた相互扶助が, 一樂の目指す「公正な社会」, すなわち「強い者が弱い者を労わり助け」, 「正直者が損をしないという経済分野」を建設するための基礎である。それは人間が本能として もつ欲をそれなりに認めつつも，しかしその野放図な発揮を，相互扶助という枠によって，その 枠を超えない程度に欲望を抑制することであり，人々がまず自分のことを考え，自分の幸せを目 的とした行動をとるのは当然だとしても，同時に他人のこと，自分の行動が他人に与える影響を

16）この説明のため, 一樂は「なさけ（情）はひと（他人）のためならず」の言葉を引用している（一樂 1979, 3). 
常に考える習慣を, 自身の行動の基準にするよう求めるものである（一樂 1984a, 41-42）。一樂 は（自由）競争原理を協同（相互扶助）原理に置き換えることが, 人類生き残りのための要件で あると言い (ibid., 40-42), 経済学に対して, 「双方の立場を理解し合って, その理解の上で協力 しあうという有機的人間関係」の「合理性を検討する, そういう経済学になってもらいたい」と も述べている（中村・一樂 1983, 51）.

（4）生活の商品依存からの脱却と手づくり

生産者だけでなく,一方で消費者自身も, この資本主義社会において商品に依存する生活になっ ている，これを変えるためには，人々の経済的な価值観を変える必要がある，価値観を変えるた めの具体的な方法が, 生活の商品依存からの脱却（消費者の自主性と学習）と, 手づくり（食べ 物・娛楽・働く喜び) である.

一樂は，有機農業を「手ゔくう農業」と呼んでおり，これは農民の知恵と労働をできる限り多 く投入し, 資金の投下はなるべく少なくするものであるという，同時に,この「手ゔくう農業」は, 消費生活面においての手づくりと並行していなければ実行され難いものである（一樂 1975b, 9). 現代の文明は，人間疎外の文明であり，資本の自己拡大のために，所得につられ，生活を犠牲に してまで儲けに奔走している，農業生産，物の消費，趣味娛楽においても，すべてをできるだけ， 手づくりを回復し発展させることを, 目指すべき根本のこととしなければならないと一樂は主張 する（一樂 1976, 35）.

\section{3. 農産物市場の是正, 牽制としての「提携」運動}

以上のように, 一樂は「公正な社会」の建設の足掛かりとして, 協同組合思想を掲げ, その実 践の形としての「生産者と消費者の提携」運動を支持した。1989 年，一樂は農政に関するイン 夕ビューの中で, 農産物の生産者・消費者が農産物市場で主体性を失っている状況において, 「産 消提携」は市場を牽制する勢力を生じさせ,「良貨が悪貨を駆逐する力関係」が期待できると述 べている. その理由は, 本来は農協や生協がその役割を担うべきであるものの, 当面は日本の協 同組合にそれを期待できないため, 生産者と消費者が提携する意味が重大である，一方，競争原 理で成り立つ商業の世界では, ほとんどの業者各自が生き延びるために自己防衛上, 公正さを欠 く手段をとることも余儀なくされる，そのため流通業界が自ら，または行政の強化によって取引 の公正化を図ることは難しい. 農産物については市場取引は万能ではなく, 農家, 消費者, 政府 はそれを認め, 市場を牽制するに足るだけの機構を生産者と消費者の協力によって構築する必要 がある，それが「生き延びるためには公正化せざるを得ない」という関係，すなわち「生産者と 消費者の提携」であり，それ以外に市場を根本的に是正する方法は求めることができないという (『現代農業』編集部 1989, 181).

前述のように, 一樂が主張する農業の商業 / 流通資本からの独立, 農産物の脱商品化の主張は, 工業や他産業への適用とは明確に区別される。一樂は，有機農業運動の二つの側面を，生産者・ 
消費者の提携という新たな社会関係をつくりあげること，および農家が商品経済への過度の依存 から脱却すること, と述べており, それは, 有機農業と「提携」運動によって, 「工業の論理」,「貨 幣価值オンリー」の価值観の「市場」を牽制することであった(『現代農業』編集部 1989, 181$83)$.

商業的流通が隈なく普及してしまって，農産物の生産者も消費者も農産物市場において 主体性をほとんど失ってしまっている状況においては，市場をある程度は牽制する勢力が 生まれなければならないんですよ。

農協や生協こそがその役割を担うべきですが，今日の我が国の協同組合には，それを期 待することはできない，とは断定したくないが，当面は無理でしょう．．..今日生産者と消 費者が提携する意味が重大であり，それにより良貨が悪貨を駆逐する力関係が期待できる のです。これ以外に，市場を根本的に是正する方法は求めることができません.

農産物については，市場取引が万能でないことを，農家も消費者も，そして政府も認め て，市場を牽制するに足るだけの機構を，生産者と消費者の協力によって構築することが 必要です。

外からの㐿制力などによらないで, 流通業界の自らの自覚によって，または行政の強化 によって取引の公正化を図ればよいのではないかとの意見もあるでしょうが，競争原理の 上に立っている商業の世界においては，ほとんどの業者各自が生き延びるため，自己防衛 上公正さを欠く手段も余儀なくされるのです，だから，生き延びるためには公正化せざる を得ない，という関係を発生させねばならないのです。（『現代農業』編集部 1989, 181)

有機農業運動は, 生産者・消費者の提携という新たな社会関係をつくりあげていくと同時 に，農家が商品経済への過度の依存から脱却するということを実現する道なのです。...有 機農業の二つの側面，と言えるでしょう.

（『現代農業』編集部 1989, 183）

\section{IV 一樂の社会経済思想の評価と今後の課題}

本稿では，一樂照雄の協同組合思想と彼の「生産者と消費者の提携の方法（提携 10 か条）」の 学説史的意義を検討した．最後に，一樂の社会経済思想の変遷を振り返りつつ，それへの暫定的 な評価を行なうとともに, 残された課題を挙げたい.

まず一樂の社会経済思想の変遷は，前述の 4 つの時代に分けられる ${ }^{17)}$.このうち一樂が最も思

17）第 2 の農林中央金庫時代（1945～58 年）および全国農業協同組合中央会時代（1958～65 年）の一樂は, 同金庫の経営立て直し，農協の系統販売体制の推進や農産物流通合理化を通じた日本農業の経済的地 位向上を目指した。一樂は後にこれについて「農政に従属した活動は, 戦後の経済復興という臨時の 国家的要請に基づくものと理解すべきものであった」（一樂, 1977）と回顧している. 
想的影響を受けた時期は，第 1 の戦前の産業組合中央金庫勤務時代（1930４5 年）で，一樂の 協同組合思想と「提携 10 か条」には, 大正期から続く日本の農本思想との共通点が多くみられ る ${ }^{18)}$. 岩崎 $(1997,349,354,362 ）$ によれば, 戦前日本の農本思想は自然委任型（大正期）, 社会 創出型 (昭和恐慌期)，国体依存型（戦時期）に分類され，それらは「不均衡な社会経済的基盤」 を背景に「農に非経済的価值を認め, その価値を擁護ないし追求・実現しょうとする思想」とし て表現された。ただし，このうち日本のファシズムイデオロギーの一つとしても機能した国体依 存型農本思想は, それまでの二つの農本思想とは断絶あるいは転向を経たものだという。確かに 一樂には, 東京帝国大学在学中の那須皓との関係や,「産業組合拡充」運動等における千石興太 郎らによる「産業組合主義」への共感がみられる。しかし一樂はいずれの時期においても「国家 への従属」を否定し, 農民/住民による自治と互助による国家および資本主義市場のオルタナティ ブを志向している．その意味では岩崎の分類による昭和恐慌期の社会創出型農本思想, なかでも 岡本利吉の『規範経済学』（1929）とその「共働」運動に近い. 岡本が, 反都会・反商工業・反 中央集権・反資本主義に基づく地域社会構想を実践し（岩崎 1997）また消費組合である協働社 の結成（1920 年）や，生産者・消費者双方にとっての正当な価格を主張する「正義眞實の合理 組織（生産は利益の鹞に行はず, 消費の爲に行ふ眞實を具體化し, 然かも生産勞働者に正當なる 勞働の報酬を保證する自然の組織)」(岡本 1922, 4）を提唱していたことも，一樂と類似する ${ }^{19)}$.

また一樂の理念,「自立互助」,「フェイス・ツー・フェイスの人情」,「家族の延長として‥苦 楽を共にする相手」，「生活の商品依存からの脱却と手づくり」は，多分に規範的である，一樂は このいわゆる「顔の見える関係」のために，提携における有機農産物「流通」において第三者で ある事業者を介さないなど, 運動から資本主義市場経済的なものを排除し, 組織運営と流通の担 い手を運動に直接携わる生産者と消費者会員に求めた。そのため株式会社形式の有機農業運動も 否定し, 産消提携運動から排除している（藤田・小松 1992）. 先の岩崎 (1997）は, 岡本利吉の『規範 経済学』について「理論信仰から導き出された『規範』は，思想的にも運動的にも必然的に統制へ の志向を生み出さざるをえなかった」と評しているが，この評価は一樂にも当てはまるだろう．

一方, 一樂の社会経済思想と岡本らによる社会創出型農本思想の違いは, 一樂が生産者の経済 的自立に必要な条件として,生産者との相互理解と互助のもとで消費者が生産物を「買い支える」 責任を喚起したこと，またそのための消費者教育と生活改革を重視したことにあるだろう. Barton $(2018,182)$ は, 英米と日本の有機農業運動の違いとして, 日本の（提携）消費者の存在 に言及しているが, これを組織し，産消提携運動に社会 / 環境消費運動としての広がりを持たせ た理念が，岡田の「消費者と農民による自給農場」構想と一樂の「提携 10 か条」である，それ

18）藤原 $(2021,24)$ は, 「農学」が, 科学技術としての合理性と生命・相互扶助・共生・有機などの「経 済外的なもの」を併せ持つために, 人びとの情念を掻き立てる生命主義や農本主義, 行動主義, 実践 主義，排外主義も生じさせてきた，と述べている.

19）堀田（2016, 131-32）はこの組織について, 生産者と消費者が互いに正当性を主張しつつ互讓の精神で 運営, 直接取引しつつ等価交換 $=$ 正義の交換を目指して協議する組織, と説明している. 
らは，有機農業運動の一形態としての農と食の運動であるだけでなく，消費者の自発的な「買い 支え」や「当事性の倫理」という意味で，今日の「倫理的消費」の一つのモデルと評価できる.

ただし繰り返すが，この貢献は一樂単独によるものではない．前述のように，第 3 の協同組合 経営研究所時代（1965～71 年）における一樂の協同組合運動の理想（全国農業協同組合中央会 ほか 1967）は, 二つの共同体構想の失敗を経て, 第 4 の有機農業研究会創設と産消提携運動時 代（1971～94 年）での各地の有機農産物生産者と提携消費者の試行錯誤，および岡田が組織し た「販路」としての消費者の共同購入グループと消費者教育の成功を待たねばならなかった．生 活圈を異にする主体間での「農と食の疑似的共同体（アソシエーション）」の維持には, 理念, 新たな農業技術，事業としての経済的基盤，社会的条件が必要であったが，一樂の社会経済思想 としての貢献は，そのうちの理念，すなわち協同原理に基づく相互理解と互助による協力という 運動指針（提携 10 か条)，そのための消費者の責任の喚起にあるだろう。また重要な点として， このとき生産者との「疑似的共同体」への「消費者の巻き込み」を可能としたのが，1960 年代 からの農薬の害や食品公害の社会問題化であり，都市消費者による既存の生産・流通システムへ の危機感であった ${ }^{201}$.

本研究の残された課題は二つある．第 1 に，「産業組合主義」を批判した近藤康男に代表され る「協同組合の流通過程合理化論」への一樂の抵抗，およびそれへの一樂による『協同組合原則 とその解明』（全国農業協同組合中央会ほか 1967）での発言がその後の産消提携グループとの交 流の中で「提携 10 か条」となる過程, 第 2 に, 産消提携運動の事業モデルと消費者組織をつくっ た岡田米雄の社会経済思想との関係，これらを明らかにすることである．今後順次検討していき たい.

《資料：一樂照雄の略歴》21)

1906（ 0 歳） 徳島県にて出生（父田村与平の三男), 小学校 5 年生のとき伯父 一樂善藏の養子 に

1930（24 歳） 東京帝国大学農学部農業経済学科卒業，産業組合中央金庫に就職 (1945 産業組合中央金庫 $\rightarrow$ 農林中央金庫)

1945 （39 歳） 農林中央金庫 高松支所長（～1948）仙台支所長（～1950）

1950（44 歳） 農林中央金庫業務部長

1954（48 歳）農林中央金庫理事

1956（50 歳） 社団法人農山漁村文化協会理事

1957（51 歳） 国際協同組合同盟（ICA）第20 回大会（ストックホルム）に出席

20）岡田など同時期の産消提携運動指導者たちの思想および産消提携運動と疎外論については, Nemoto 2021 を参照のこと.

21）農山漁村文化協会（2009）の巻末略歴・関連事項年表より拔粋して作成. 
1958（52 歳） 全国農業協同組合中央会理事に就任

1965（59歳） 全国農業協同組合中央会理事を辞任

財団法人協同組合経営研究所理事，翌年に理事長

1971（65 歳） 有機農業研究会設立, 幹事に就任

1975（69 歳）生産者と消費者の提携に乗り出す

1978（72 歳）「生産者と消費者の提携の方法（提携 10 か条）」を提案

1984（78 歳） 日本有機農業研究会代表幹事に就任

財団法人協同組合経営研究所理事長を退任

1987 （81 歳） 日本有機農業研究会代表幹事を退任, 顧問へ

1994（87 歳）逝去

(根本志保子：日本大学)

\section{参 考 文 献}

Barton, G. A. 2018. The Global History of Organic Farming. Oxford: Oxford University Press.

Henderson, E. and R. Van En. 2007. Sharing the Harvest: A Citizen's Guide to Community Supported Agriculture, rev. ed. White River Junction, Vt.: Chelsea Green. 山本きよ子訳『CSA 地域支援型農業の可能性一アメリカ版 地産地消の成果』家の光協会, 2008.

Holyoake, G. J. [1893] 1900. The History of the Rochdale Pioneers, 10th ed. London: Swan Sonnenschein \& Co. 協 同組合経営研究所訳『ロッチデールの先駆者たち』協同組合経営研究所, 1968.

International Co-operative Alliance. [1966] 1967. Report of the I. C.A. Commission on Co-operative Principles. London: International Co-operative Alliance.

Nemoto, S. 2021. Socio-economic Thought of the Teikei Movement and the Early Organic Agriculture in Japan:

Overcoming 'Natural and Human Alienation.' Bulletin of Research Institute of Economic Science College of Economics Nihon University 51:107-21.

Rodale, J. I. 1945. Pay Dirt: Farming \& Gardening with Composts. New York: Devin-Adair. 一樂照雄訳『有機農 法一自然循環とよみがえる生命』協同組合経営研究所, 1974.

安全な食べ物をつくって食べる会 30 年史刊行委員会. 2005. 『村と都市を結ぶ三芳野菜一無農薬・無化学肥 料 30 年』ボロンテ.

一樂照雄. 1959a.「これからの農協運動」『農業協同組合』8月号 : 14-30.

一. 1959 b. 「農民の政治教育」『農業協同組合』12月号 : 12-19.

—. 1964.「農業政策にのぞむ」『農業協同組合』4月号 : 36-44.

—.1966 a. 「自立経営と農協」『協同組合経営研究月報』 $156: 2$.

——1966b.「農業者の主体性と農協」『農業と経済』33 (1): 26-32.

—. 1967 a. 「消費者の主体性」『協同組合経営研究月報』163:2.

—. 1967b. 「開会の挨掺 (研究総会特集)」『協同組合経営研究月報』164:2-4.

—. 1967 c. 「協同組合原則と日本の農協」『協同組合経営研究月報』171:2-16.

—. 1968. 「近郊農村の村づくり一協同組合による農住都市の建設」『協同組合経営研究月報』176:46-50.

—. 1969.「農住都市づくりの構想」『土地住宅総合研究』19:32-37.

—. 1972.「この情勢に協同組合はどう対処するか」『協同組合経営研究月報』224:18-28. 
—. 1973.「現代協同組合運動の基本問題について」『協同組合経営研究月報』235:11-26.

—. 1975 a. 「特集日本農業転換への道一有機農業の提唱」『地上』家の光協会 5 月号 : 22-29.

—. 1975b.「有機農業とはなにか」『月刊百科』157:8-11.

—. 1976. 「協同組合運動の現代に抢ける課題」『協同組合経営研究月報』274:23-35.

—. 1977. 「有機農業研究が当面する諸問題」『土と健康』54:1-2.

—. 1979.「生産者と消費者の提携の方法について」『土と健康』78:2-6.

—.1980a.「これからの社会と協同組合」『協同組合経営研究月報』319:54-61.

—.1980b.「シューマッハー氏とその著書」『土と健康』99:16-17.

一一. 訳. 1980c. 「Schumacher, E. F. : 一経济学徒の農業観」『協同組合経営研究月報』326:1-12.

—. 1984 a. 「現代社会と協同組合」『協同組合経営研究月報』365:35-53.

—.1984b.『協同組合の使命と課題』農山漁村文化協会.

岩崎正弥. 1997. 『農本思想の社会史一生活と国体の交錯』京都大学学術出版会.

岡田米雄. 1971.「なぜ飲め如“ンモノ牛乳”一日本農業の象徵的問題として」『朝日ジャーナル』13(45): 40-44.

岡本利吉. 1922. 「消費組合と其聯盟」『新組織』4(3): 1-4.

一. 1929.『規範経済学』平凡社.

加山久夫. 2018.「協同組合運動の原点と未来一賀川豊彦と一楽照雄」『雲の柱』32:23-37.

協同組合経営研究月報編集. 1982 a. 「協同組合間提携の実践と考え方一農水産物の協同組合間提携研究会記 録一第 1 日」『協同組合経営研究月報』341:40-60.

—. 1982b. 「協同組合間提携の実践と考元方一農水産物の協同組合間提携研究会記録一第 2 日」『協同組合 経営研究月報』342:49-64.

久保田裕子. 2008. 「『天地有機』と東西の有機農業運動の源流一日本有機農業研究会の結成と『有機農業』 という言葉をめぐって」『国学院経済学』(国学院大学経済学会) 56 (3・4): 553-89.

黒沢西蔵. 1971. 「吾が農業観」『協同組合経営研究月報』214:2-18.

『現代農業』編集部. 1989.「有機農業に対する農水省の理解をただす一日本有機農業研究会の一楽照雄氏は 語る」『現代農業』1月号：178-83.

佐藤寬次. 1918.『信用組合論』産業組合中央会.

—.1936.『産業組合講和』成美堂書店.

全国農業協同組合中央会·全国漁業協同組合連合会·日本生活協同組合連合会·財団法人協同組合経営研究所,

編. 1967.『協同組合原則とその解明』協同組合経営研究所.

平 實. 1941.『産業組合の基礎理念』日本評論社.

高松 修. 2001. 『有機農業の思想と技術』コモンズ.

舘野廣幸. 2012.「有機農家からみた日本の有機農業と関倸する思想家たち」『社会科学論集』(埼玉大学経済 学会) 136:61-68.

露木裕喜夫. 1982.『自然に聴く一生命を守る根源的智慧』露木裕喜夫遺稿集刊行会.

手島福一・池尻文二・勝部欣一・一樂照雄. 1968.『協同組合とは一新しい協同組合原則の解説を中心にして』 協同組合経営研究所.

中村達也・一樂照雄. 1983.「食糧は商品であってよいのか」『協同組合経営研究月報』362:43-60.

那須 皓・東畑精一. 1932.『協同組合と農業問題』改造社.

農山漁村文化協会, 編. 1996 a. 『一樂照雄伝』一樂照雄伝刊行会.

—. 1996b.『暗夜に種を播く如く一樂照雄伝 普及版』一樂照雄伝刊行会.

一一. 2009. 『暗夜に種を播く如く一樂照雄一協同組合·有機農業運動の思想と実践』協同組合経営研究所（同 
編 1996a および 1996b の復刻版).

原＼cjkstart洪太. 2019.「一楽照雄が提唱した農住都市構想と農林省による農村住宅団地建設計画の関係性に関する 研究」『都市計画論文集』54 (3)：593-99.

福島土といのちを守る会・十周年記念誌編集委員会. 1991.『有機農業運動に生きて』福島土といのちを守る 会・十周年記念誌編集委員会.

藤田和芳・小松光一. 1992.『いのちと暮らしを守る株式会社』学陽書房.

藤原辰史. 2021.『農の原理の史的研究一「農学栄えて農業亡ぶ」再考』創元社.

堀田＼cjkstart泉． 2016.『消費組合論一「消費」の再定義に向けて』風媒社.

桝潟俊子. 2008. 『有機農業と〈提携〉のネットワーク』新曜社.

梁瀬義亮. 1975. 『有機農業革命一污れなき土に播け』ダイヤモンド社.

—. 1978. 『生命の医と生命の農を求めて』柏樹社. 


\title{
Teruo Ichiraku's Socioeconomic Thoughts and the Japanese teikei Movement Promoting Organic Agricultural Products
}

\author{
Shihoko Nemoto
}

\begin{abstract}
:
This paper examined Teruo Ichiraku's (1906-1994) thoughts on co-operative societies and the economic aspects of his 'Ten Principles of teikei' formulated in 1978.

Ichiraku held high-ranking positions in several co-operative organisations and founded the Japan Organic Agriculture Association in 1971. He was influenced by pre-Second World War Japanese cooperativism and peasantism. He found his co-operative ideal in the teikei system started by organic farmers and consumer groups, some of which were organised by Yoneo Okada, and supported it as an alternative to the capitalist market systems dominated by monetary values. The teikei system involves a direct partnership between producers and consumers, eliminating commercial distributions and building reciprocal face-to-face relationships.

According to Ichiraku, Japanese agriculture was unjustly pulled into exchange economies by industrial policies after the Meiji Restoration. He argued that the agriculture sector should have the same footing as other sectors, and that agricultural products should not be commodities for anonymous individuals in the market for three reasons: food is a necessity; Japanese agriculture is practised by small families; and it doesn't allow farmers to determine the price, because the distribution processes are controlled by the commercial capitals.

However, a personal relationship with partners enables the evaluation of agricultural products in use-value, independence from the price-determining features of commercial markets, and a 'no-lying' relationship with respect to the pricing and the use of pesticides and other harmful chemicals.

Ichiraku encouraged 'a face-to-face sympathy based on humanity,' which underlay the 'Ten Principles of teikei,' to control human greed within the framework of mutual assistance-the requirement for realising 'a fair society.' Compared with Japanese peasantism, teikei's uniqueness is that it stimulated consumers to buy and support agricultural products based on mutual understanding and reciprocity.
\end{abstract}

JEL classification numbers: B30, Q00. 